\title{
Peertechz
}

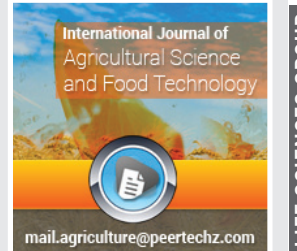

\section{Evaluation of the effect of the} supplementation of Agaricus brasiliensis mushroom in cytohematological, growth

\section{and stress parameters in Nile tilapias (Oreochromis iloticus)}

\section{Flávio F Silva ${ }^{1,2}$, Alessandra Hugo de Souza ${ }^{2}$ and Wiliam CB Regis $^{1-3 *}$}

${ }^{1}$ Nutrition Science Department, Pontifical Catholic University of Minas Gerais, Belo Horizonte, Brazil

${ }^{2}$ Graduate Program in Vertebrate Biology, ${ }^{3}$ Biological and Health Institute, Pontifical Catholic University of Minas Gerais, Belo Horizonte, Brazil

${ }^{3}$ Graduate Program in Nutrition and Health, Federal University of Minas Gerais, Belo Horizonte, Brazil
Received: 31 August, 2020

Accepted: 05 November, 2020

Published: 07 November, 2020

*Corresponding author: Wiliam CB Regis, Graduate Program in Nutrition and Health, Federal University of Minas Gerais, Belo Horizonte, Av. Dom José Gaspar, 500 - Coração Eucarístico, Belo Horizonte, Brazil, Tel: +55 31992417276;

E-mail:wcbregis@gmail.com; wregis@pucminas.br Keywords: Agaricus brasiliensis; Agaricus blazei; Tilapia; Pisciculture; Supplementation

https://www.peertechz.com

Check for updates

\begin{abstract}
Currently, in fish farming, Nile tilapia farming is one of the most widespread types worldwide and is present on all continents. However, stressors are normal in intensive rearing systems, which triggers immune suppression leading to a higher chance of infection, with Aeromonas hydrophila being one of the main responsible for the frequent diseases. Inhibition of reproductive and growth performance are also frequently observed in these situations. Thus, it is more than necessary to develop efficient treatments not only against the immune damage generated by stress in fish but also to prevent oxidative stress itself as well as against its side effects related to physiology and infections. The mushroom Agaricus brasiliensis is widely recognized in the literature for its immunomodulatory and antioxidant effects, which makes it a potential supplement to counteract the effects of stress on intensive fish farming. In this study, we evaluated the effects of supplementation with the mushroom Agaricus brasiliensis through a randomized clinical trial regarding the immunological hematological variables in face of a normal situation and an induced stress situation as well as in the face of an immunological challenge by Aeromonas hydrophila. The mushroom proved to have a positive effect under the tested conditions, however, further studies will be necessary to determine its definitive effects.
\end{abstract}

\section{Introduction}

Nile tilapia farming is one of the most widespread types of fish farming in the world and is present on all continents [1]. In this type of farming, cropping systems can be classified as extensive, semi-intensive and intensive systems such as Raceway's, which are characterized by high risk and productivity environments due to the stress caused by the conditions of creation [2]. The stress factors in fish that are commonly found in these breeding systems [3] may be physical, environmental or social [4], with plasma cortisol being the predominant factor in the stress mechanism [5]. The main biochemical effects triggered by stress and release of cortisol in fish are the alteration of osmotic and ionic regulation 
[6], reduction of mobilization of circulating leukocytes and lymphocytes [5] and reduction of the rate of growth and suppression of immune and reproductive functions [7]. Given this fact, a frequent problem in aquatic animal populations is the occurrence of diseases, since water acts as a facilitator of transmission of pathogens in a population of the same species [8]. Many natural products have been described to be safe to use on acquacuture like extracts from clove seed used to sedate fish for different farm operations [9]. This study further revealed that the extracts could be safely applied at $100.0 \mathrm{mg} / \mathrm{l}$, which is sufficient to anaesthetize the fish with little or no changes on its heamatological parameters.

Among the diseases observed in fish, those caused by bacteria are the ones with the greatest risk potential, since bacteria of economic importance for fish farming are present in fish water and microbiota [10], in captivity annual losses associated with streptococcus are approximately 150 million dollars [11].

The Mushroom Agaricus brasiliensis has always been reported in the literature as a potent antioxidant and immunomodulator, and currently arouses great scientific and economic interest due to its well documented properties [12], and can be used in fish farming and aquaculture to avoid sanitary problems and excessive use of antibiotics [13]. In the case of direct cytohematological parameters, it is not new that the supplementation of the A. brasiliensis mushroom can stimulate responses. In 1998 its potential benefits were already elucidated by stimulating the production of lymphocytes [14]. Supplementation of this mushroom under normal conditions may also increase the number of circulating eosinophils and macrophages [15]. However, in the case of the immunomodulation promoted by this mushroom, the stimulatory effect on monocytes is also described be the activity of isolated fractions of A. brasiliensis [12]. A single study evaluated the supplementation of this mushroom in tilapia, however, in a short experimental period, but still, are be observed an increase in immature leukocytes [16].

The objective of this work was to evaluate the cytohematological, growth and weight effects associated with the supplementation with the mushroom Agaricus brasiliensis, juveniles of Nile tilapia in normal conditions and the situation of stress and in front of immunological challenge by Aeromonas Hydrophila.

\section{Methodology}

The present study was carried out at the Pontifical Catholic University of Minas Gerais (PUC-Minas), under the registration of protocol no. 029/2017 of the Ethics Committee on the Use of Animals - CEUA PUC Minas. Nile tilapia (Oreochromis niloticus) juveniles, housed in two circular tanks of 300 liters at a density of 15 liters / fish, we used a mean temperature of $27 \pm 1.2$ in a 12-h photo-light period: $12 \mathrm{~h}$ light $/ 12 \mathrm{~h}$ dark and after the acclimation period, the experimental treatments were different for each tank, consisting of a control diet composed of commercial ration and an experimental diet composed of commercial ration enriched with $1 \%$ with Agaricus brasiliensis during 90 days prior to stress induced by starvation [17] Feeding was done at will once a day (4:30 p.m.), so that there was not too much leftover in the tanks. A commercial feed with $32.0 \%$ digestible protein was used, both for mushroom enrichment and control diet. To perform the enrichment, the feed was ground and the mushroom Agaricus brasiliensis was added in $1 \%$ dry weight, $60 \%$ humidified, extruded and dried by exposure to the sun for 24 hours. For evaluation of hematological parameters, four fish were randomly removed per treatment and anesthetized with $1.0 \mathrm{ml} / \mathrm{L}$ Eugenol. After anesthesia, blood was collected utilizing a puncture of the caudal vessel with $1.0 \mathrm{ml}$ syringe, bathed with anticoagulant (EDTA 5.0\%) and blood (0.5 ml) collected was stored in heparin tubes and taken immediately for analysis in the laboratory DMVET. The fish submitted to blood collection were separated in another tank with the same environmental conditions and after the effect of the anesthesia were reallocated in the tank of the experiment/control.

\section{Immunological challenge}

For this experiment, 100 Nile tilapia (Oreochromis niloticus) fingerlings were used and maintained in two circular tanks of $300 \mathrm{l}$ in the density of 50 fingerlings per tank, at a mean temperature of $27 \pm 1.2$ in a photo-lighting period of $12 \mathrm{~h}: 12 \mathrm{~h}$ light / dark and after the acclimation period, the experimental treatments were different for each tank, consisting of a control diet composed of commercial feed and an experimental diet composed of commercial feed enriched with $1 \%$ with Agaricus brasiliensis for 30 days. Shortly after the stress period the fish were challenged by Aeromonas hydrophila (ATCC7966) via intraperitoneal injection in low doses (1 x 10-4 CFU) or saline solution to $0.9 \%$. The appearance of clinical signs was observed for 10 days. After this period, the fish were challenged again with a dose of $7.1 \times 10-2 \mathrm{CFU}$ of the same bacterium via intraperitoneal injection and were then observed for the next 10 days or until death.

Statistical analyses were performed in the Bioestat 5.0 program, the t-tests of Student are used.

\section{Results}

\section{Biometric analysis between groups (90 days)}

The tables below (Tables 1,2) present the mean and initial and final standard deviation for the size of the groups tested.

Although not statistically significant, the A. brasiliensis mushroom showed a tendency to retard fish weight gain and growth rate. Regarding weight a slight retard was noted at the end of the experiment, but also did not present a significant difference $(\mathrm{P}>0.05)$ (Tables 3,4).

Table 1: Initial fish size comparison (pre-treatment).

\begin{tabular}{|c|c|c|}
\hline \multicolumn{3}{|c|}{ Initial size between groups } \\
\hline Group & Medium $(\mathbf{c m})$ & Standard Deviation $(\mathbf{\pm})$ \\
\hline Control & 23.25 & 1.36 \\
\hline Experiment & 22.8 & 2.6 \\
\hline
\end{tabular}

Experiment starts 0.45 lower 


\section{Cytohematological effect of supplementation (90 days)}

Initially, a baseline study was carried out to determine if both treatments started from the same immunological conditions (Tables 5- 8) and, as expected, no significant difference was observed between the analyzes performed $(\mathrm{P}>$ 0.05), indicating that the groups started the experiments under statistically similar conditions.

From the information that the groups did not show differences in the number of initial leukocytes, the experimental period between groups (Table 9-12) was analyzed and we observed that the number of circulating monocytes was statistically lower in the supplemented group $(\mathrm{P}<0.05)$. This result indicates that the supplementation with the $A$. brasiliensis mushroom was able to modify this immunological variable between groups. Regarding eosinophils, they did not present significant numbers for statistical analysis.

Table 2: Final fish size comparison (post-treatment).

\begin{tabular}{|c|c|c|}
\hline \multicolumn{3}{|c|}{ Final size between groups } \\
\hline Group & Medium $(\mathbf{c m})$ & Standard Deviation $\mathbf{( \pm )}$ \\
\hline Control & 26.6 & 1.36 \\
\hline Experiment & 26 & 2.6 \\
\hline Experiment ends 0.6 lower & & \\
\hline
\end{tabular}

Table 3: Initial comparison of fish weight (pre-treatment).

\begin{tabular}{|c|c|c|}
\hline \multicolumn{3}{|c|}{ Initial weight between groups } \\
\hline Group & Medium & Standard Deviation $(\mathbf{\pm})$ \\
\hline Control & 253 & 61 \\
\hline Experiment & 220.16 & 69.3 \\
\hline Experiment starts with -33.14 g compared to control \\
\hline
\end{tabular}

Table 4: Final fish weight comparison (post-treatment).

\begin{tabular}{|c|c|c|}
\hline \multicolumn{3}{|c|}{ Final weight between groups } \\
\hline Group & Medium & Standard Deviation ( $\mathbf{\pm})$ \\
\hline Control & 333,2 & 44.17 \\
\hline Experiment & 250,2 & 101.1 \\
\hline
\end{tabular}

Experiment ends with -83g compared to control

Table 5: Initial analysis of lymphocyte levels between control and experiment groups.

\begin{tabular}{|c|c|c|}
\hline \multicolumn{3}{|c|}{ Initial lymphocytes between groups (\%) } \\
\hline Group & Medium & Standard Deviation $( \pm)$ \\
\hline Control & 76.87 & 11.15 \\
\hline Experiment & 82.75 & 7 \\
\hline$P>0.05(0.40)$ & & \\
\hline
\end{tabular}

Table 6: Initial analysis of neutrophil levels between control and experiment groups.

\begin{tabular}{|c|c|c|}
\hline \multicolumn{3}{|c|}{ Initial neutrophils between groups (\%) } \\
\hline Group & Medium & Standard Deviation $(\mathbf{\pm})$ \\
\hline Control & 19.62 & 9.28 \\
\hline Experiment & 13.37 & 6.89 \\
\hline
\end{tabular}

$P>0.05(0.32)$
Table 7: Initial analysis of monocyte levels between control and experiment groups.

\begin{tabular}{|c|c|c|}
\hline \multicolumn{3}{|c|}{ Initial monocytes between groups (\%) } \\
\hline Group & Medium & Standard Deviation $( \pm)$ \\
\hline Control & 1.87 & 1 \\
\hline Experiment & 3.25 & 1.9 \\
\hline$P>0.05(0.25)$ & & \\
\hline
\end{tabular}

Table 8: Initial analysis of eosinophil levels between control and experiment groups.

\begin{tabular}{|c|c|c|}
\hline \multicolumn{2}{|c|}{ Initial Eosinophils between groups (\%) } \\
\hline Group & Medium & Standard Deviation $( \pm)$ \\
\hline
\end{tabular}

\begin{tabular}{c|c|c} 
Control & 0.37 & 0.47 \\
\hline Experiment & 0.62 & 1.25
\end{tabular}

$P>0.05(0.77)$

Table 9: Analysis of post-treatment lymphocyte levels between control and experiment groups.

\begin{tabular}{|c|c|c|}
\hline \multicolumn{3}{|c|}{ Lymphocytes after $\mathbf{9 0}$ days of control test vs experiment $(\%)$} \\
\hline Group & Medium & Standard Deviation $\mathbf{(} \mathbf{)}$ \\
\hline Control & 77.5 & 15.84 \\
\hline Experiment & 87.75 & 8.61 \\
\hline$P>0.05(0.29)$ & & \\
\hline
\end{tabular}

Table 10: Analysis of post-treatment neutrophil levels between control and experiment groups.

\begin{tabular}{|c|c|c|}
\hline \multicolumn{3}{|c|}{ Neutrophils After $\mathbf{9 0}$ days of control test vs. experiment (\%) } \\
\hline Group & Medium & Standard Deviation $\mathbf{(} \mathbf{)}$ \\
\hline Control & 19 & 15.34 \\
\hline Experiment & 11 & 7.79 \\
\hline $\mathrm{P}>0.05(0.23)$ & & \\
\hline
\end{tabular}

Table 11: Analysis of post-treatment monocyte levels between control and experiment groups.

\begin{tabular}{|c|c|c|}
\hline \multicolumn{3}{|c|}{ Monocytes Post $\mathbf{9 0}$ days of control test vs experiment (\%) } \\
\hline Group & Medium & Standard Deviation $\mathbf{(} \mathbf{)}$ \\
\hline Control & 3.5 & 1 \\
\hline Experiment & 1.25 & 1.25 \\
\hline $\mathrm{P}>0.05(0.04)^{\star}$ & & \\
\hline
\end{tabular}

Table 12: Analysis of post-treatment eosinophil levels between control and experiment groups.

\begin{tabular}{|c|c|c|}
\hline \multicolumn{2}{|c|}{ Eosinophils After $\mathbf{9 0}$ days of control test vs experiment (\%) } \\
\hline Group & Medium & Standard Deviation $\mathbf{(} \mathbf{)}$ \\
\hline Control & 0.375 & 0.48 \\
\hline Experiment & 0.625 & 1.25 \\
\hline$P>0.05(0.87)$ & & \\
\hline
\end{tabular}

When the post-stress variables between groups were assessed, no significant differences were observed (Tables 1316).

\section{Biometric analysis of supplementation (30 days)}

Below (Tables 17,18), we compared fish weight at the 
beginning and at the end of the experiment between groups and as expected, a significant difference ( $p>0.05$ ) was observed, showing that the mushroom had no negative effect on growth. The same result can be observed with respect to size (Tables $19,20)$.

\section{Survival challenge}

In the challenge of survival against infection we can observe a higher mortality related to the supplementation with the mushroom Agaricus blazei (Table 21).

Table 13: Comparison of lymphocyte levels between post-stress groups.

\begin{tabular}{|c|c|c|}
\hline \multicolumn{3}{|c|}{ Post-stress lymphocytes between groups (\%) } \\
\hline Group & Medium & Standard Deviation $(\mathbf{\pm})$ \\
\hline Control & 86.6 & 7.5 \\
\hline Experiment & 85 & 7.9 \\
\hline
\end{tabular}

$\mathrm{P}>0.05(0.70)$

Table 14: Comparison of neutrophil levels between post-stress groups.

\begin{tabular}{|c|c|c|}
\hline \multicolumn{3}{|c|}{ Post-stress neutrophils between groups (\%) } \\
\hline Group & Medium & Standard Deviation ( \pm ) \\
\hline Control & 7.5 & 3.87 \\
\hline Experiment & 6.25 & 2.62 \\
\hline$P>0.05(0.46)$ & & \\
\hline
\end{tabular}

Table 15: Comparison of monocyte levels between post-stress groups.

\begin{tabular}{|c|c|c|}
\hline \multicolumn{3}{|c|}{ Post-stress monocytes between groups (\%) } \\
\hline Group & Medium & Standard Deviation $(\mathbf{\pm})$ \\
\hline Control & 2.75 & 2.06 \\
\hline Experiment & 9 & 9 \\
\hline$P>0.05(0.26)$ & & \\
\hline
\end{tabular}

Table 16: Comparison of eosinophil levels among post-stress groups.

\begin{tabular}{|c|c|c|}
\hline \multicolumn{3}{|c|}{ Post-stress eosinophils between groups (\%) } \\
\hline Group & Medium & Standard Deviation ( $\mathbf{\pm})$ \\
\hline Control & 0.25 & 0.5 \\
\hline Experiment & 0 & 0 \\
\hline$P>0.05(0.60)$ & & \\
\hline
\end{tabular}

Table 17: Initial comparison of fish weight (pre-treatment).

\begin{tabular}{|c|c|c|}
\hline \multicolumn{3}{|c|}{ Initial weight between groups (30 days) } \\
\hline Group & Medium & Standard Deviation $\mathbf{(} \mathbf{)}$ \\
\hline Control & 3 & 1.23 \\
\hline Experiment & 3.14 & 1.21 \\
\hline
\end{tabular}

Table 18: Final fish weight comparison (post-treatment).

\begin{tabular}{l|l|l|} 
Final weight between groups (30 days) \\
\hline Group & Medium & Standard Deviation $( \pm)$ \\
\hline Control & 15.6 & 5.9 \\
\hline Experiment & 16.6 & 4.7
\end{tabular}

Table 19: Initial fish size comparison (pre-treatment).

\begin{tabular}{|c|c|c|}
\hline & \multicolumn{3}{|c|}{ Initial size between groups (30 days) } \\
\hline Group & Medium & Standard Deviation $\mathbf{(} \mathbf{)}$ \\
\hline Control & 5.5 & 0.75 \\
\hline Experiment & 5.64 & 0.58 \\
\hline
\end{tabular}

Table 20: Final fish size comparison (post-treatment).

\begin{tabular}{|c|c|c|}
\hline \multicolumn{3}{|c|}{ Final size between groups (30 days) } \\
\hline Group & Medium & Standard Deviation $\mathbf{(} \mathbf{)}$ \\
\hline Control & 9.4 & 1.26 \\
\hline Experiment & 9.3 & 1.21 \\
\hline
\end{tabular}

Table 21: Mortality observed in challenge of infection.

\begin{tabular}{|c|c|c|c|}
\hline \multirow{2}{*}{ Day } & \multicolumn{2}{|c|}{ Mortality rates (\%) } & Signs \\
\cline { 2 - 4 } & Control & Experiment & not observed \\
\hline 1 to 5 & none & none & not observed \\
\hline 5 to 10 & none & none & \\
\hline Day & \multicolumn{2}{|c|}{ Second challenge } & not observed \\
\hline 1 to 5 & Control & Experiment & not observed \\
\hline 5 to 10 & none & $100 \%$ & \\
\hline
\end{tabular}

\section{Discussion}

In this study, even slightly, the A. brasiliensis mushroom proved to be able to modulate the immune response of Nile tilapia concerning the number of circulating monocytes, and in fish, in general, the innate defense is mainly composed of monocytes, macrophages and granulocytes (lymphocytes) [18] and just like in mammals, circulating monocytes give macrophage origin [19]. During an inflammation or an infectious process, monocyte levels can be increased, being one of the major cells involved in acute inflammation as part of the innate immune response [20], thus, the reduction of circulating monocytes observed in the results presented, may indicate that there was a reduction in acute inflammation, which is possibly generated by the capture management itself [21], this idea are reinforced by the confirmation that monocytes are the main producers of cytokines and secrete free radicals [22,23].

In immunostimulatory-based diets containing PAMPs, recognition and activation pathways are unclear [22], but TLRs play a crucial role in both innate and adaptive immunity. Its ability to detect PAMPs is related to the inflammatory response [24] and although there are more than 17 types of TLRs identified in fish, it is possible that the function of TLR4, one of the main monocyte modulation sites of the mushroom $A$. brasiliensis [21,25] has been lost in teleosts [26], thus explaining the low immunomodulatory response to supplementation.

Another fact that should be taken into account is that for immunostimulants, such as $\beta$-glucan, the route of administration is a determinant factor in the immune response, especially in the case of tilapia, since the supply of immunostimulants via feed produces an effect attenuation in the cells of the immune system when compared to the supply via immersion and intraperitoneal injection, in regard to monocyte, leukocyte, and lymphocyte counts. This result is 
also observed when we compared the oral immunostimulant intake against a control diet [27].

The results of our study corroborate with another results presented [16], thus bringing the concept that low doses of this mushroom did not present a strong immunomodulatory activity in tilapias, similar results were observed in FOS supplementation studies [28].

Recently, it was evidenced that hypoxia stress can generate alterations in the immune system of fish [29], but to date, the effect of starvation on the count of circulating leukocytes in fish has not been investigated. Thus, based on the results presented in this paper, we suggest that the response to starvation may not trigger significant immunological changes in adult 0 . niloticus, or that fish may present different mechanisms of non-cortisol-dependent immune response.

Ichthyologists consider changes in leukocyte differential counts as one of the most sensitive indicators of acute stress in fish because there is a close link between leukocyte profiles and glucocorticoid levels. High neutrophil rates for lymphocytes in blood samples strongly indicate high levels of glucocorticoids as acute responses to stress [30]. In this work we can observe a higher neutrophil: lymphocyte ratio for both groups post stress period when compared to the non-stress period, we observed that the treatment with $A$. brasiliensis was also able to maintain this score calculated by the neutrophil: lymphocyte ratio at 0.7 after the stress period, whereas in the control group the score was approximately 0.9 which may indicate a lower stress in the supplemented group.

It was elucidated that there was an interesting difference, although not statistically significant among the means of the weight of the groups, where A. brasiliensis tended to delay the weight gain in approximately $20 \%$ in the supplemented group, also, we observed a higher mortality rate for the experimental group.

This mushroom has 33.14 to $54.22 \%$ of carbohydrates [31], which represents a considerable increase (0.3g to $0.54 \mathrm{~g} / \mathrm{kg}$ ) of carbohydrates in the supplementation since the diet control is carbohydrate-free. The low capacity of fish to use dietary carbohydrates is reported by inadequate regulation in the use (glycolysis) and production (gluconeogenesis) of hepatic glucose [32], which can also lead to a higher mortality or lead to losses in fish growth and weight gain [33]. In fish fed a highcarbohydrate diet compared to a high-protein diet, a lower rate of weight gain and a specific growth rate can be observed [34]. The studies are not conclusive as to the carbohydrate content; however, apparently Nile tilapia supports high carbohydrate dosages [35]. In our second attempt we observed that the mushroom had no negative effects on the physiological aspects of tilapia growth and weight. However, the effects on growth and weight may be dependent on the amount of $ß$-glucan incorporated into the diet, duration of feeding, room temperature and the species under study [36].

\section{Infection challenge}

Although knowledge about Aeromonas hydrophila is limited, its virulence has already been elucidated against aquatic populations. Among the virulence factors already documented for A. hydrophila, hemolysins, arabinasins, proteases, adhesins, enterotoxins, phospholipase and lipase, enzymes leading mainly to hemorrhagic septicemia in stressed fishes [37].

We observed a systemic response to the second challenge of bacteria, where the fish supplemented died soon after the application. One of our hypotheses is the hyper reaction caused by supplementation, however, glucans alone or in combination with PAMPs or bacterial injection do not cause apoptosis in organs related to the immune system [38]. Another plausible biochemical pathway is the interaction between the biochemical mechanisms of the pathway of Agaricus brasiliensis and Eugenol. It has recently been shown that Eugenol can act synergistically with cisplatin increasing its chemotherapeutic potential by mainly inhibiting the transcription factor pathway (NF$\mathrm{kB}$ ) [39]. The mushroom, on the other hand, modulates the immune response of enterocytes, reducing the translocation of $\mathrm{NF}-\mathrm{kB}$ in Caco-2 cells [40].

In addition to acting as a stress mediator, $\mathrm{NF}-\kappa \mathrm{B}$ is constitutively present in neurons participating in physiological functions of the CNS, such as synapse, development and neural plasticity, therefore, an exacerbated physiological response to a stressor agent, resulting in a drastic reduction of the level of this neurotransmitter, could result in death.

\section{Highlights}

This first clinical trial randomized presents a new supplementation with potential benefits; this is the first study of Agaricus brasiliensis mushroom supplementation in fish; this study brings new possibilities for study.

\section{Conclusion}

Based on our findings, we can conclude that the supplementation with the mushroom Agaricus brasiliensis is justified in the pisciculture by the potential immunomodulatory activity and, possibly, antioxidant effect, without bringing any physiological losses in terms of yield and biomass conversion in short periods of supplementation.

\section{Acknowledgment}

We thankCAPES for the scholarship offered to the researcher, ANILAB for analysis help, and PUC-MG. This research did not receive any specific grant from funding agencies in the public, commercial, or not-for-profit sectors.

\section{References}

1. FAO (2019) Agricultural Data. Food and Agriculture Organization of the United Nations. Disponível. Link: https://bit.ly/36bjNVq

2. MANUAL TÉCNICO, 21 Pereira, Augusto da Costa Produção de tilápias/ Augusto da Costa Pereira, Rodrigo Fróes Silva. Niterói: Programa Rio Rural, 2012;1(1).

3. Hein G, Brianese RH (2004) Modelo Emater de produção de tilápia. EMATEREmpresa de Assistência Técnica e Extensão Rural 1. 
4. Tort $L$ (2011) Stress and immune modulation in fish. Dev Comp Immunol 35 . Link: https://bit.ly/3eyycyH

5. Oba E (2009) Fish leukocyte responses. In: Feldman BF. Zinkl JG, Jain NC. Vet Hem , (Ed. Fifth).

6. Da Silva RD, Rocha LO, Fortes BDA, Vieira D, Fioravanti MCS (2012) Parâmetros hematológicos e bioquímicos da tilápia-do-nilo (Oreochromis niloticus L.) sob estresse por exposição ao ar. Pesquisa Veterinaria Brasileira. 32. Link: https://bit.ly/38fk3oP

7. Shaw FD, Tume RK (1992) The assessment of pre-slaughter and slaughter treatments of livestock by measurement of plasma constituents-A review of recent work. Meat Sci 32: 331-329. Link: https://bit.ly/3n4a6Pv

8. Melo CCV, Costa DV, Gonçalves ACS, Leira MH, Botelho HA, et al. (2016) Desenvolvimento dos tecidos muscular e adiposo em linhagens de tilápia do Nilo Oreochromis niloticus. Caderno de Ciências Agrárias 72-82.

9. Akinrotimi O (2015) The Efficacy of Clove Seed Extracts as an Anaesthetic Agent and Its Effect on Haematological Parameters of African Catfish (Clarias Gariepinus). International Journal of Aquaculture and Fishery Sciences. Link: https://bit.ly/3exDZEP

10. Leira, MH, Lago AA, Botelho AH, Melo CCV, Mendonça GF, et al. (2016) Principais Infecções Bacterianas $\mathrm{Na}$ Criação De Peixes De Água Doce Do Brasil-Uma Revisão. Rev Ciência Veterinária e Saúde Pública 3. Link: https://bit.ly/2IdJqwC

11. Fagundes LC, Eto SF, Marcusso PF, Fernandes DC, Marinho-Neto FA, et al. (2016) Passive transfer of hyperimmune serum anti Streptococcus agalactiae and its prophylactic effect on Nile tilapia experimentally infected. Arquivo Brasileiro de Medicina Veterinaria e Zootecnia 68. Link: https://bit.ly/34ZYW81

12. Hetland G, Johnson E, Lyberg T, Bernardshaw S, Tryggestad AMA, et al. (2008) Effects of the medicinal mushroom Agaricus blazei Murill on immunity, infection and cancer. Scand J Immunol 68: 363-370. Link: https://bit.ly/3elEZGh

13. Bernardshaw S, Johnson E, Hetland G (2005) An extract of the mushroom Agaricus blazei murill administered orally protects against systemic Streptococcus pneumoniae infection in mice. Scand J Immuno 62: 393-398. Link: https://bit.ly/3p19ago

14. Mizuno M, Morioto M, Minato K, Tsuchida H (1998) Polysaccharides from Agaricus blazei stimulate lymphocyte T-cell subsets in mice. Biosc Biotech Biochem 62: 434-437. Link: https://bit.ly/3p4bmUf

15. Fanhani JC, Murakami AE, Guerra AFQG, do Nascimento GR, Pedroso RB, e al. (2016) Agaricus blazei in the diet of broiler chickens on immunity, serum parameters and antioxidant activity. Semina:Ciencias Agrarias 37: 2235-2246. Link: https://bit.ly/38fVvw7

16. Schalch SHC, Abimorad EG, Onaka EM, Fonseca FS, Castellani FGD (2015) Hematological parameters of tilapia (Oreochromis niloticus) fed with supplemented diet based on the mushroom Agaricus blazei. Bioikos. 29. Link: https://bit.ly/3k48tiT

17. El-Khaldi ATF (2010) Effect of different stress factors on some physiological parameters of Nile tilapia (Oreochromis niloticus). Saudi Journal of Biological Sciences 17: 241-246. Link: https://bit.ly/32iyZii

18. Choi K, Lehmann DW, Harms CA, Law JM (2007) Acute hypoxia-reperfusion triggers immunocompromise in Nile Tilapia. J Aquat Anim Health 19: 128140. Link: https://bit.ly/3ewNPXd

19. Magnadóttir B (2006) Innate immunity of fish (overview). In: Fish and Shellfish Immunology.

20. Cruvinel W de M, Mesquita Júnior D, Araújo JAP, Catelan TTT, Souza AWS de et al. (2010) Sistema imunitário: Parte I. Fundamentos da imunidade inata com ênfase nos mecanismos moleculares e celulares da resposta inflamatória. Revista Brasileira de Reumatologia 50. Link: https://bit.ly/321xhN7

21. Martins Pilarsky F, Onaka E, Nomura E, Ribeiro K, Myiazaki D, et al. (2018) Hematologia e resposta inflamatória aguda em Oreochromis niloticus (Osteichthyes: Cichlidae) submetida aos estímulos único e consecutivo de estresse de captura. Boletim do Instituto de Pesca 30

22. Vallejos-Vidal E, Reyes-López F, Teles M, MacKenzie S (2016) The response of fish to immunostimulant diets. Fish Shellfish Immunol 56: 34-69. Link: https://bit.ly/350I7de

23. Ellis AE (1999) Immunity to bacteria in fish. Fish and Shellfish Immunology 9 : 291-308. Link: https://bit.ly/3naLjcD

24. Vidya MK, Kumar VG, Sejian V, Bagath M, Krishnan G, et al. (2018) Tolllike receptors: Significance, ligands, signaling pathways, and functions in mammals. Int Rev Immunol 37: 20-36. Link: https://bit.ly/3mXQjRt

25. Liu W, Ge M, Hu X, Lv A, Ma D, Huang X, et al. (2017) The Effects of Agaricus blazei Murill Polysaccharides on Cadmium-Induced Apoptosis and the TLR4 Signaling Pathway of Peripheral Blood Lymphocytes in Chicken. Biol Trace Elem Res 180: 1153-163. Link: https://bit.ly/2JIUOkH

26. Tanekhy M (2016) The Role of Toll-like Receptors in innate immunity and infectious diseases of teleost. 47, Aquaculture Research. 47.

27. Sado RY, Gimbo RY, Salles FB (2016) Routes of $\beta$-glucan administration affect hematological and immune responses of Oreochromis niloticus. Archivos de Zootecnia 65: 519-524. Link: https://bit.ly/32iYtfE

28. Soleimani N, Hoseinifar SH, Merrifield DL, Barati M, Abadi ZH (2012) Dietary supplementation of fructooligosaccharide (FOS) improves the innate immune response, stress resistance, digestive enzyme activities and growth performance of Caspian roach (Rutilus rutilus) fry. Fish Shellfish Immuno 32 316-321. Link: https://bit.ly/3p2E7R

29. Abdel-Tawwab M, Monier MN, Hoseinifar SH, Faggio C (2019) Fish response to hypoxia stress: growth, physiological, and immunological biomarkers. Fish Physiology and Biochemistry 45. Link: https://bit.ly/2IcKL6t

30. Davis AK, Maney DL, Maerz JC (2008) The use of leukocyte profiles to measure stress in vertebrates: A review for ecologists. Functional Ecology 22: 760-772. Link: https://bit.ly/3lahKr2

31. Shibata CKR, Demiate IM (2003) CULTIVO E ANÁLISE DA COMPOSIÇÃO QUÍMICA DO COGUMELO DO SOL (Agaricus blazei Murril)(Cultivation and chemical analysis of the sun mushroom (Agaricus blazei Murril)). Publicatio UEPG: Ciências Biológicas e da Saúde 9. Link: https://bit.ly/3oX2UX7

32. Enes $P$, Panserat $S$, Kaushik S, Oliva-Teles A (2009) Nutritional regulation of hepatic glucose metabolism in fish. Fish Physiol Biochem 35: 519-539. Link: https://bit.ly/3p2FijP

33. Favero G (2010) Níveis de carboidratos em dietas extrusadas para tilápiasdo-nilo revertidas ou não sexualmente. Aleph 1. Link: https://bit.ly/3mV6MG8

34. Zhou C, Ge X, Liu B, Xie J, Chen R, Miao L, et al. (2017) Comparative study on the effect of high dietary carbohydrate on the growth performance, body composition, serum physiological responses and hepatic antioxidant abilities in Wuchang bream (Megalobrama amblycephala) and black carp (Mylopharyngodon piceus Richardson, 1846). Aquaculture Research 48: 10201030. Link: https://bit.ly/366VgAU

35. Boonanuntanasarn S, Kumkhong S, Yoohat K, Plagnes-Juan E, Burel C, et al (2018) Molecular responses of Nile tilapia (Oreochromis niloticus) to different levels of dietary carbohydrates. Aquaculture 482. Link: https://bit.ly/3p4fdAH

36. Skjermo J, Størseth TR, Hansen K, Handå A, Øie G (2006) Evaluation of $\beta-(1$ $3,1 \quad 6)$-glucans and High-M alginate used as immunostimulatory dietary supplement during first feeding and weaning of Atlantic cod (Gadus morhua L.). Aquaculture 261: 1088-1101. Link: https://bit.ly/3n1bH8m

Citation: Silva FF, De Souza AH, CB Regis W (2020) Evaluation of the effect of the supplementation of Agaricus brasiliensis mushroom in cytohematological, growth and stress parameters in Nile tilapias (Oreochromis iloticus). Int J Agric Sc Food Technol 6(2): 218-224. OI: https://dx.doi.org/10.17352/2455-815X.000077 
37. Parker JL, Shaw JG (2011) Aeromonas spp. clinical microbiology and disease. J Infect 62: 109-118. Link: https://bit.ly/3k5Gqzg

38. Miest JJ, Falco A, Pionnier NPM, Frost P, Irnazarow I, et al. (2012) The influence of dietary $\beta$-glucan, PAMP exposure and Aeromonas salmonicida on apoptosis modulation in common carp (Cyprinus carpio). Fish and Shellfish Immunology 33: 846-856. Link: https://bit.ly/3p0e4dz

39. Islam SS, Al-Sharif I, Sultan A, Al-Mazrou A, Remmal A, et al. (2018) Eugenol potentiates cisplatin anti-cancer activity through inhibition of ALDH-positive breast cancer stem cells and the NF-KB signaling pathway. Mol Carcinog 57: 333-346. Link: https://bit.ly/3I8Q05W

40. Ayeka PA (2018) Potential of Mushroom Compounds as Immunomodulators in Cancer Immunotherapy: A Review. Evidence-based Complementary and Alternative Medicine 2018. Link: https://bit.ly/38ghcfq
Discover a bigger Impact and Visibility of your article publication with Peertechz Publications

\section{Highlights}

* Signatory publisher of ORCID

* Signatory Publisher of DORA (San Francisco Declaration on Research Assessment)

* Articles archived in worlds' renowned service providers such as Portico, CNKI, AGRIS, TDNet, Base (Bielefeld University Library), CrossRef, Scilit, J-Gate etc.

* Journals indexed in ICMJE, SHERPA/ROMEO, Google Scholar etc.

* OAI-PMH (Open Archives Initiative Protocol for Metadata Harvesting)

* Dedicated Editorial Board for every journal

* Accurate and rapid peer-review process

* Increased citations of published articles through promotions

* Reduced timeline for article publication

Submit your articles and experience a new surge in publication services

(https://www.peertechz.com/submission).

Peertechz journals wishes everlasting success in your every endeavours.

Copyright: @ 2020 Silva FF, et al. This is an open-access article distributed under the terms of the Creative Commons Attribution License, which permits unrestricted use, distribution, and reproduction in any medium, provided the original author and source are credited.

Citation: Silva FF, De Souza AH, CB Regis W (2020) Evaluation of the effect of the supplementation of Agaricus brasiliensis mushroom in cytohematological, growth and stress parameters in Nile tilapias (Oreochromis iloticus). Int J Agric Sc Food Technol 6(2): 218-224. Ol: https://dx.doi.org/10.17352/2455-815X.000077 